Clinical science

\title{
COMPARATIVE ANALYSIS OF HIDDEN BLOOD LOSS IN TOTAL KNEE ARTHROPLASTY
}

\author{
Gavrilovski Antonio, Shabani llir ${ }^{1}$, Velkovski Vilijam¹, Todorova Teodora1 ${ }^{1}$, Shaban Memeti² \\ University Clinic for Traumatology, Orthopedics, Anesthesiology, Reanimation and Intensive Care; Ss Cyril and \\ Methodius University in Skopje, Faculty of Medicine, Republic of North Macedonia \\ University Clinic for children's surgery; Ss. Cyril and Methodius University in Skopje, Faculty of Medicine, Repub- \\ lic of North Macedonia
}

Citation: Gavrilovski A, Shabani I, Velkovski V,
Todorova T, Memeti Sh. Comparative analysis of hid-
den blood loss in total knee arthroplasty. Arch Pub
Health 2021;13 (2). 1-5
doi.org/10.3889/aph.2021.6013
Key words: total knee arthroplasty, hidden blood
loss, tourniquet
*Correspondence: Antonio Gavrilovski. University
Clinic for Traumatology, Orthopedics, Anesthesio-
ogy, Reanimation and Intensive Care; Ss Cyril and
Methodius University in Skopje, Faculty of Medicine,
Republic of North Macedonia.
E-mail: gavrilovski@gmail.com
Received: 20-Jan-2021; Revised: 8-Sep-2021;
Accepted: 20-Sep-2021; Published: 25-Sep-2021
Copyright: ${ }^{-2021 . ~ B A n t o n i o ~ G a v r i l o v s k i, ~ I l i r ~}$
Shabani, Vilijam Velkovski, Teodora Todorova,
Shaban Memeti. This is an open-access article
distrib-uted under the terms of the Creative
Commons Attribution License, which permits
unrestricted use, distribution, and reproduction
in any medium, provided the original author(s)
and source are credited.
Competing Interests: The author have declared
that no competing interests

Клинички истражувања

\begin{abstract}
The aim of the study was to investigate the influential factors for hidden blood loss after a total knee arthroplasty and their relationship with the total blood loss. Total knee arthroplasty (TKA) is a crucial treatment of late-stage knee osteoarthritis. Measured blood loss is significantly inconsistent with the hemoglobin (HB) drop postoperatively. Fifty-four patients, 20 males and 34 females, were retrospectively analyzed. The preoperative blood loss and therefore the hidden blood loss following TKA were calculated by the Gross formula. The typical perioperative blood loss was found to be $780 \pm 220 \mathrm{ml}$ and therefore the average hidden blood loss was $280 \pm 180 \mathrm{ml}$. No significant differences were found in hidden blood loss for males compared to females. Hidden blood loss may not be reduced by hemostasis during operation with a deflated tourniquet.
\end{abstract}

\section{КОМПАРАТИВНА АНАЛИЗА НА СКРИЕНАТА ЗАГУБА НА КРВ ПРИ ИЗВЕДУВАҢЕ ТОТАЛНА АРТРОПЛАСТИКАНА КОЛЕНОТО}

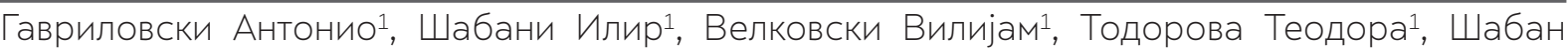
Мемети

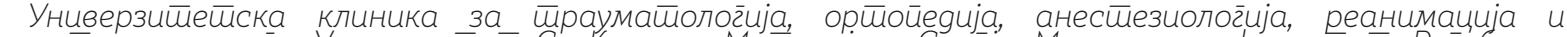

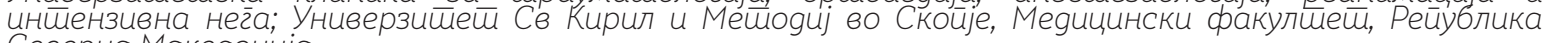
Северна Makegoнuja

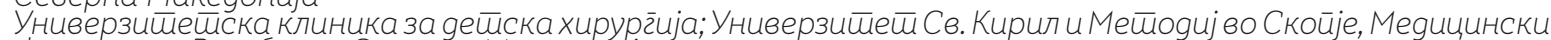
факулйей, Рейублика Северна Макеgонија
}

Цитирање: Гавриловски А, Шабани И, Велко-
вски В, Тодорова Т, Мемети Ш.
Компаративна анализа на скриената загуба на
крв при изведување тотална артропластика на
коленото. Арх J Здравје 2021;13(2) 1-5
doi.org/10.3889/арh.2021.6013
Клучни зборови: тотална артропластика на
колено, скриена крвозагуба, турнике
„Кореспонденција: Антонио Гавриловски.
Универзитетска клиника за детска хирургија;
Универзитет Св. Кирил и Методиј во Скопје,
Медицински факултет, Република Северна
Македонија
Е-таil: gavrilovski@gmail.com

Примено: 20-јун-2021; Ревидирано: 8-сеп-2021; Прифатено: 20-сеп-2021; Објавено: 25-сеп-2021 Печатарски права: ${ }^{\circledR 2021}$ Антонио Гавриловски, Илир Шабани, Вилијам Велковски, Теодора Тодорова, Шабан Мемети. Оваа статија е со отворен пристап дистрибуирана под условите на нелокализирана лиценца, која овозможува неограничена употреба, дистрибуција и репродукција на било кој медиум, доколку се цитираат оригиналниот(ите) автор(и) и изворот.

Конкурентски интереси: Авторот изјавува дека нема конкурентски интереси.

\section{Извадок}

Целта на овој труд беше да се пронајдат факторите кои влијаат врз скриениот губиток на крв како и нивниот сооднос со целосната крвозагуба при тотална алоартропластика. Тоталната алоартропластика на коленото (ТКА) е важна процедура во третманот на остеоартритисот на коленото во напредната фаза. Измерената загуба на крв често пати е несразмерна со падот на хемоглобинот (НВ) постоперативно.

Ретроспективно беа анализирани 54 пациенти, 20 мажи и 34 жени. Периоперативната загубана крв и скриената загуба на крв по ТКА беа пресметани со формулата на Грос (Gross).

Просечната периоперативна загуба на крв беше $780 \pm 220 \mathrm{ml}$, а просечната скриена загуба на крв беше $280 \pm 180 \mathrm{ml}$.

Не беа најдени значителни разлики кај скриената загуба на крв кај мажите во споредба со жените. Скриената загуба на крв не може да се намали со внимателна хемостаза за време на операцијата. 


\section{Introduction}

Total knee arthroplasty (TKA) may be a gold standard treatment for endstage knee osteoarthritis. This surgery is considered the foremost effective treatment for severe knee osteoarthritis with good or excellent long-term outcomes ${ }^{1,2,3}$. It represents a serious orthopaedic surgery which involves a significant blood loss due to bone cuts and soft tissue releases. Approximately 15 million transfusions are performed annually worldwide caused by TKA ${ }^{4}$.

In this surgery the blood loss consists of the visible blood loss from the wound drainage, into the tissues which is hidden and the surgical field. The measured blood loss usually consists of measurement of the drained blood and therefore the real blood loss could also be underestimated. Despite the usage of a tourniquet during TKA and the significant improvement in surgical techniques, this surgery is related to a large amount of post-operative blood loss and remains a topic for discussion among surgeons. Lotke et al. came to a conclusion that the mean blood loss in TKA when calculated from pre-operative drop by hemoglobin was 1518 $\mathrm{ml}$, which needed a minimum of one transfusion $^{5}$. Transfusion increases the danger of transmission of infectious diseases, anaphylactic, hemolytic and immunologic reactions. Also, it could lead to a longer hospital stay and increased mortality ${ }^{6}$.

The existing results of influential factors in these patients remain controversial. Identifying the factors of surgical blood loss may be a crucial step towards establishing an efficient blood management strategy and reducing the necessity of peri-operative transfusion. Cushner and Friedman et al. discovered that the gender of patients may influence the blood loss; transfusion rates were higher in females probably owing to lower preoperative hemoglobin levels, but they excluded the correlation with the age and duration of the surgery ${ }^{7}$.

The aim of our study was to detect and recognize the potential influencing factors of hidden blood loss in patients with knee osteoarthritis, treated with total knee arthroplasty.

\section{Materials and methods}

The study was performed at the University Clinic for Orthopaedic Surgery from December 2018 to December 2019. A total of 54 patients, of whom 20 males and 34 females with knee osteoarthritis were retrospectively analyzed. We calculated the perioperative blood loss and consequently the hidden blood loss by using the Gross formula?

The formula is as follows: for male, $\mathrm{PBV}=\mathrm{k} 1 \mathrm{xh} 3+\mathrm{k} 2 \mathrm{xw}+\mathrm{k} 3$ (h- height $(\mathrm{m}) ; \mathrm{w}$ - weight $(\mathrm{kg}) ; \mathrm{k} 1=0.3669, \mathrm{k} 2$ = 0.03219 and $\mathrm{k} 3=0.6041$; for female $\mathrm{k} 1$ $=0.3561, \mathrm{k} 2=0.03308$ and $\mathrm{k} 3=0.1833$ ). Total blood loss was calculated by multiplying PBV by the change of HCT. Patients with anemia or any other disorder of hemoglobin preoperatively were excluded from this study. Potential factors who may affect operative and hidden blood loss were gender, surgical time, tourniquet time, hemostasis (during surgery with deflating tourniquet). In the group without tourniquet the tourniquet was released before closure of the wound and hemostasis was done and in the group with tourniquet the wound was closed without releasing it.

In all of the patients a typical surgical technique was used. All of the patients were operated under spinal anaesthe- 
sia. We used a tourniquet which was inflated $120 \mathrm{~mm}$ above the systolic blood pressure. We used the medial parapatellar surgical approach. Cemented cruciate retaining prosthesis was used. Blood loss intraoperatively was measured from the suction device. We put active vacuum drain in every patient. The drain was removed after 48 hours. Hemoglobin and hematocrit levels were measured before and after surgery (after spinal anaesthesia was over, day 2 and day 4 postoperatively). The total blood loss (during the operation and collected from the drain) was compared to the $\mathrm{Hb}$ levels on selected days. In patients who received blood transfusion we made correction of the $\mathrm{Hb}$ level by $1 \mathrm{~g} / \mathrm{dL}$ for every unit. After that we made the conversion of these numbers to HCT value.

\section{Results}

In this study, the mean operative time was 115 minutes (100-190 minutes) and the mean tourniquet time was 107 minutes (80-120 minutes). Intraoperative blood loss of the group with hemostasis using the deflated tourniquet was $155 \mathrm{ml}(90-300 \mathrm{ml})$ and postoperative drain-blood volume was 595 \pm 205 $\mathrm{ml}$ for that group. Perioperative blood loss was $780 \pm 220 \mathrm{ml}[(758 \pm 243) \mathrm{ml}$ for females and $(912 \pm 90) \mathrm{ml}$ for males] and hidden blood loss was $280 \pm 180 \mathrm{ml}$ $[(240 \pm 185) \mathrm{ml}$ for females and $(410 \pm 125)$ $\mathrm{ml}$ for males]. The hidden blood loss was therefore $(51 \pm 9.3) \%$ of the visible postoperative blood loss (Table 1). The lowest hematocrit levels were measured on the 2-4 postoperative day, and the percentage of the hidden blood loss in both sexes was nearly equivalent. Although male patients had higher levels of hidden blood loss than females $(\mathrm{t}=-2.022, \mathrm{P}=0.049)$, the proportion volume was nearly equivalent (Table 1). Hidden blood loss might be reduced by hemostasis after deflating tourniquet during the intraoperative period ( $\mathrm{t}=-2.068, \mathrm{P}=0.041)$, but the preoperative blood loss was not affected $(\mathrm{t}=-1.819 \mathrm{P}=0.073)$ (Table 2).

Table 1. Gender distribution of perioperative blood loss

\begin{tabular}{|c|c|c|c|}
\hline & Perioperative blood loss (ml) & Hidden blood loss (ml) & Percentage \\
\hline Female $(n=34)$ & $758 \pm 243$ & $240 \pm 185$ & 51.1 \\
\hline Male $(\mathrm{n}=20)$ & $912 \pm 90$ & $410 \pm 125$ & 50.7 \\
\hline$P$ value & 0.010 & 0.049 & 0.372 \\
\hline
\end{tabular}

Table 2. Distribution of blood loss with and without hemostasis

\begin{tabular}{|l|c|c|}
\multicolumn{2}{|c|}{ Perioperative blood loss $(\mathrm{ml})$} & Hidden blood loss (ml) \\
\hline With tourniquet & $780 \pm 220$ & $300 \pm 105$ \\
\hline Without tourniquet & $595 \pm 205$ & $280 \pm 180$ \\
P value & 0.073 & 0.041
\end{tabular}

\section{Discussion}

Hidden blood loss (HBL) was usually ignored until year 2000 when it was formally suggested [8]. Several theories were proposed like the idea of Pattison and Faris who suggested that HBL could also be due to hemolysis 9,10. On the opposite, Erskine proposed that the loss went into tissue compartments by using labelled 
red cells 11. Other theory suggests that free fatty acids generated from fatty emboli in blood circulation are liable for the hidden blood loss by peroxidation damage of membrane molecules of red blood cells and hemoglobin. Tranexamic acid, closed-suction drainage, body mass index (BMI), gender and anticoagulants can also influence HBL. However, the factors have not been fully clarified 12-20.

Ward et al. revealed the mathematical solution to the hidden blood loss in 1980, and in 1983 the concept was moved forward by Gross PBV = k1 xh3 + k2 xw + k3 (h - height - height (m); $\mathrm{w}$ - weight (kg); for male, $\mathrm{k} 1=0.3669$, $\mathrm{k} 2=0.03219$ and $\mathrm{k} 3=0.6041$; for female, $\mathrm{k} 1=0.3561, \mathrm{k} 2=0.03308$ and $\mathrm{k} 3=0.1833)$. Total blood loss was calculated by multiplying PBV by the change of HCT 21-23. This new linear formula was projected using patients average hematocrit during the preoperative course. Patients who underwent a surgery were tested by the Gross equation. It had been found that this formula closely followed the logarithmic one unless there was rapid hemorrhage when the formula drifted apart, and thanks to this reason, complicated cases with large losses were excluded from this study. To some extent, Gross equation reflects the actual postoperative blood loss due to individual factors: weight, height, gender and transfusion. This equation does not involve $\mathrm{Hb}$-related factors like anemia and actual blood loss is revealed by the calculated pre-operative blood volume and the changes in HCT, which can limit this method.

\section{Conclusion}

No significant differences might be found in hidden blood loss in males compared to females. Hidden blood loss remains the same even after hemostasis during operation with a deflating tourniquet.

\section{References}

1. Insall JN, Dorr LD, Scott RD, Scott WN. Rationale of the Knee Society clinical scoring system . Clin OrthopRelat Res 1989;248:13-4.

2. Font-Rodriguez DE, Scuderi GR, Insall JN. Survivorship of cemented total knee arthroplasty. Clin OrthopRelat Res 1997;345:79-86.

3. Ranawat CS, Padgett DE, Ohashi Y. Total knee arthroplasty for patients younger than 55 years. Clin Orthop Relat Res 1989;248:27-33.

4. Walker RH. Transfusion risks. Am J Clin Pathol 1987; 88:374

5. Lotke PA, Faralli VJ, Orenstein EM, Ecker ML. Blood loss after total knee replacement: effect of tourniquet release and continuous passive motion. J Bone Joint Surg [Am] 1991;73-A:1037-40.

6. Fiebig E. Safety of the blood supply. Clin Orthop Relat Res 1998;357:6-18

7. Cushner FD, Friedman RJ. Blood loss in total knee arthroplasty. Clin Orthop Relat Res 1991; 269:98-101

8. Sehat KR, Evans R, Newman JH. What proportion blood is basically lost in total knee arthroplasty Correct blood loss management should take hidden loss under consideration. Knee 2000;7:151-5

9. Pattison E, Protheroe K, Pringle RM, Kennedy AC, Dick WC. Reduction in haemoglobin after knee surgery. Ann Rheum Dis 1973;32:582-4.

10. Faris PM, Ritter MA, Keating EM, Valeri CR. Unwashed filtered bleed 
collected after knee and hip arthroplasties. A source of autologous red blood cells. J Bone Joint Surg Am 1991;73:1169-78.

11. Erskine JG, Fraser C, Simpson R, Protheroe K, Walker ID. Blood loss with knee replacement. J R Coll Surg Edinb 1981;26:295-7.

12. Bao N, Zhou L, Cong Y, Guo T, Fan W, Chang Z, et al. Free fatty acids are liable for the hidden blood loss in total hip and knee arthroplasty. Med Hypotheses 2013;81:104-7.

13. Good L, Peterson E, Lisander B. Tranexamic acid decreases external blood loss but not hidden blood loss in total knee replacement. Br J Anaesth 2003;90:596-9.

14. Zhou XD, Wu LD. Do we actually need tranexamic acid in total hip arthroplasty? A meta-analysis of 19 randomized controlled trials. Arch Orthop Trauma Surg 2013;133:1017-27.

15. Zhou XD, Li J, Xiong Y, Jiang LF, Li WJ, Wu LD. Do we actually need closed-suction drainage in total hip arthroplasty? A meta-analysis. Int Orthop. 2013;37:2109-18.

16. Zhao J, Li J, Zheng W, Liu D. Low body mass index and blood loss in primary total hip arthroplasty: results from 236 consecutive Marie-Strumpell disease patients. BioMed Res Int 2014;2014:742393.

17. Cushner FD, Friedman RJ. Blood loss in total knee arthroplasty. Clin OrthopRelat Res 1991;269:98-101.

18. Shen HL, Li Z, Feng ML, Cao GL. Analysis on hidden blood loss of total knee replacement in end stage knee osteoarthritis. Chin Med J (Engl) 2011;124:1653-6.

19. Li J, Zhou Y, Jing J, Zhan J. Results on hidden blood loss after total hip replacement with two different anticoagulants. Chin J Reparative Reconstr Surg 2013;27:432-5.

20. Bell TH, Berta D, Ralley F, Macdonald SJ, McCalden RW, Bourne RB, et al. Factors affecting perioperative blood loss and transfusion rates in primary total joint arthroplasty: a prospective analysis of 1642 patients. Can J Surg 2009;52:295-301.

21. Ward CF, Meathe EA, Benumof JL, Trousdale F. A computer nomogram for blood loss replacement. Anaesthesiology 1980;53:S126

22. Gross JB. Estimating allowable blood loss: corrected for dilution. Anaesthesiology 1983;58:277-80.

23. Prasad N, Padmanabhan V, Mullaji A. Blood loss in total knee arthroplasty: An analysis of risk factors. Int Orthop. 2007;31:39-44. 
